\title{
Carbon balance of the continuous permafrost zone of Russia
}

\author{
Tatyana P. Kolchugina, Ted S. Vinson \\ Department of Civil Engineering, Oregon State University, Corvallis, Oregon 97331, USA
}

\begin{abstract}
An increase in the atmospheric concentration of $\mathrm{CO}_{2}$ is projected to cause climate warming. Warming of the permafrost environment could change the balance between carbon accumulation and decomposition processes and substantially disrupt the equilibrium of the carbon cycle. Warming may accelerate the rate of decomposition, which is limited by low temperatures, and thaw deeper layers of formerly frozen organic soils, making them available for decomposition. At the same time, productivity of vegetation may increase in response to warming. The continuous permafrost zone occupies approximately $40 \%$ of Russian territory, and $5 \%$ of the land surface area of the world. Disruption of the carbon cycle within the permafrost zone in Russia could have a profound effect on the global terrestrial carbon cycle. To evaluate changes in the carbon cycle within the permafrost environment of Russia, it is necessary to quantify the present carbon pools and fluxes. Once the carbon balance is established under the present climate, potential disruptions under a warming climate can be identified. A framework to assess the carbon balance for the continuous permafrost zone of Russia was created. Under the present climate, the phytomass (live vegetation, above- and below-ground) carbon pool was $17.0 \mathrm{Gt}\left(10^{9} \mathrm{t}\right)$. The mortmass (coarse woody debris) carbon pool was $16.1 \mathrm{Gt}$. The litter carbon pool was $6.4 \mathrm{Gt} C$ and the soil carbon pool including peatlands was $139.4 \mathrm{Gt}$. Live vegetation and plant detritus (mortmass and litter) taken together were approximately one-third of the soil carbon pool. The

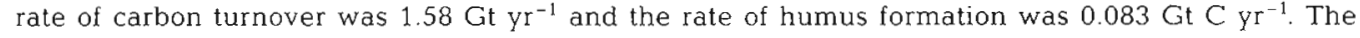
phytomass carbon pool of the permafrost zone was $19 \%$ of the former Soviet Union (FSU) phytomass pool and $3 \%$ of the world biomass carbon pool. The permafrost zone accumulated a significant amount of above- and below-ground plant detritus (mortmass and litter). Climate warming may cause forest migration to the north and increase net carbon accumulation in shrubby tundra ecosystems and ecosystems on soils of low permeability, compensating for possible carbon losses from tussock tundra. Shrubby tundra formations and gleyic soils occupy approximately one-half of the area of the Russian tundra biome. The degradation of permafrost would not directly affect the rate of carbon emissions from mineral soils and peatlands. The present depth of the active layer (i.e. layer of seasonal freezing and thawing) in mineral soils exceeds the depth of the organic horizons. In peatlands, thawing of the active layer could cause an additional mass of organic matter to become available for decomposition. However, thawing of the active layer in peatlands may not be this extensive because of the low thermal conductivity and high latent heat capacity of peat.
\end{abstract}

\section{INTRODUCTION}

The long-term ecological consequences of change in the chemical composition of the atmosphere (increase in the atmospheric concentration of carbon dioxide, $\mathrm{CO}_{2}$ ) are not fully understood; however, a warmer global climate is highly probable (IPCC 1990). If $\mathrm{CO}_{2}$ concentrations were to double, the earth's temperatures could rise between 1 and $5^{\circ} \mathrm{C}$ (Schneider 1990). Climate warming at northern latitudes could be several times greater than the global average with
'... as much as 10 to $20^{\circ} \mathrm{C}$ warming locally near the ice sheets...' (Schneider 1990). The temperature increase in high latitudes might be more pronounced in winter (Etkin 1990).

Permafrost describes a thermal condition in soil or rock when the temperature of the ground remains below $0^{\circ} \mathrm{C}$ for 2 or more years. In the continuous zone permafrost exists everywhere beneath the land surface. One of the consequences of warming the permafrost environment may be associated with the equilibrium of the carbon cycle. Changes in mean annual 


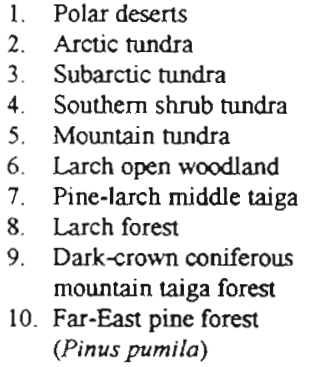

11. Scattered larch forest

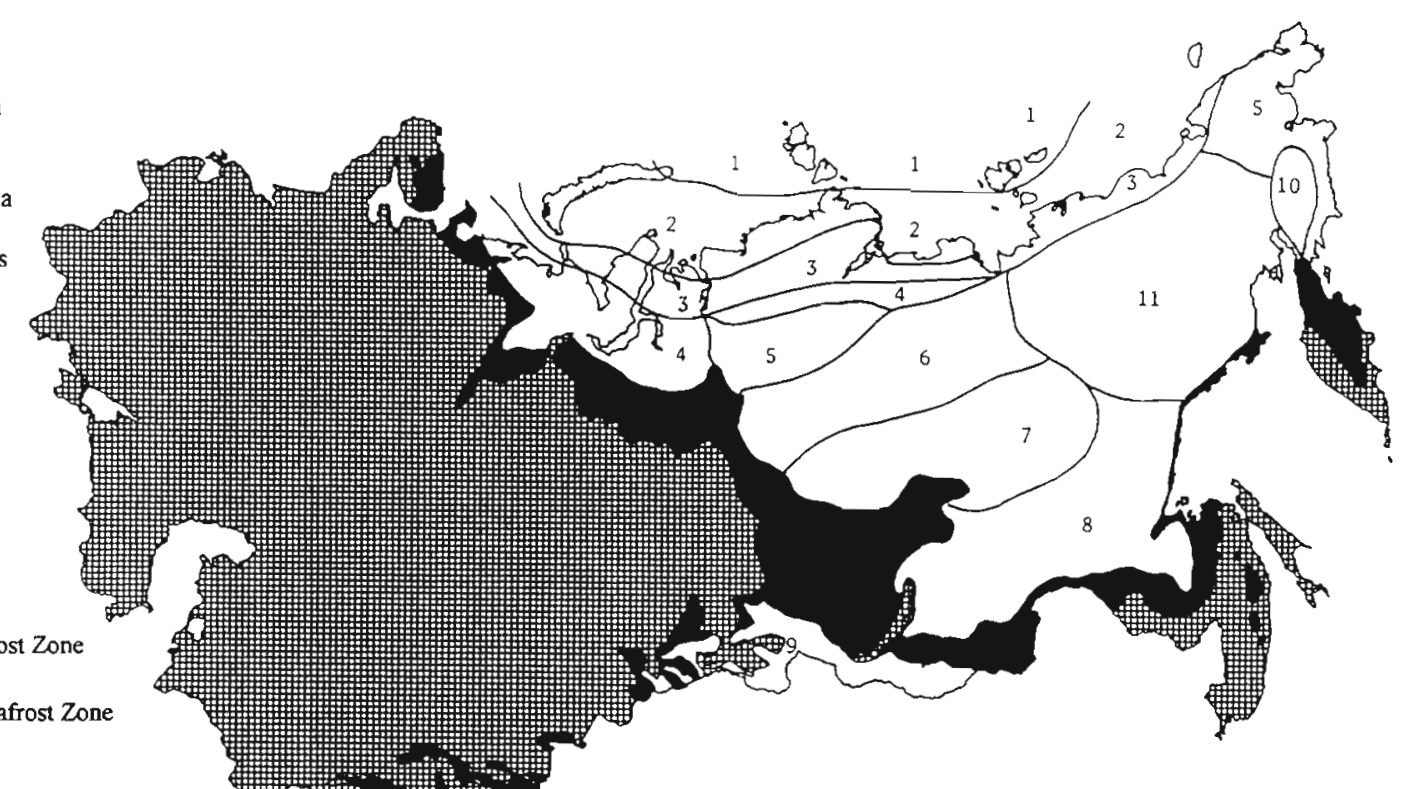

Fig. 1. Vegetation in the continuous permafrost zone of Russia (after Yershov et al. 1985, Botch pers. comm. 1992) temperatures may disrupt the balance between accumulation and decomposition processes. Warming can affect the length of the growing season, soil aeration, and nutrient availability, and result in a profound increase in plant productivity (Chapin \& Shaver 1981, Billings et al. 1982, Chapin 1984, Shaver et al. 1992), Climate warming may accelerate the rate of decomposition of organic matter, which is controlled in the arctic by low temperatures and high soil moisture (French 1977, Chapin et al. 1980, Heal et al. 1981, Dixon \& Turner 1991, Nadelhoffer et al, 1992, Oechel \& Billings 1992, Oechel et al. 1993).

The depth of the active layer (i.e. layer of annual freezing and thawing) of permafrost may double with warming (Smith \& Riseborough 1983, Kane et al. 1991). With permafrost degradation deeper layers of formerly frozen organic soils, if present, would be subject to decomposition and contribute to the total ecosystem carbon efflux. Further, if permafrost thaws, soil waterlogging is possible. Combined with higher temperatures, this may increase methane $\left(\mathrm{CH}_{4}\right)$ emissions from wetlands that have already been recognized as a source of methane in the atmosphere (Bartlett et al. 1985, Harriss et al. 1985). Although the $\mathrm{CH}_{4}$ concentration is much lower than the concentration of $\mathrm{CO}_{2}, \mathrm{CH}_{4}$ is 20 times more effective per molecule than $\mathrm{CO}_{2}$ as a greenhouse gas (Blake \& Rowland 1988).

Gas hydrates are widespread in regions with low mean surface temperatures and geothermal gradients (Davidson et al. 1978). They also occur naturally in deep ocean environments. In continental environ- ments, gas hydrates exist in the permafrost regions of the world. The total reservoir of methane carbon sequestered in gas hydrates associated with permafrost is $540 \mathrm{Gt}\left(10^{9} \mathrm{t}\right.$ ) (Kvenvolden \& Grantz 1990). Gas hydrates may be destabilized with global climate warming and permafrost degradation (Kvenvolden 1988 a). The destabilization of gas hydrates through global climate warming in the near-shore regions of the Arctic Ocean '... may have some effect, but this effect will probably be minimal, at least during the next 100 years' (Kvenvolden 1988b).

World arctic ecosystems store 61 Gt of carbon (Oechel 1989) of which more than $50 \mathrm{Gt} \mathrm{C}$ is concentrated below-ground as dead organic matter (Oechel et al. 1993). A positive feedback of some arctic ecosystems to climate warming may contribute $170 \mathrm{Mt}$ $\left(10^{6} \mathrm{t}\right){\mathrm{C} \mathrm{yr}^{-1}}^{-1}$ to the atmosphere (Oechel et al. 1993) on the global scale.

Russia has the greatest expanse of arctic deserts, tundra, northern taiga, and permafrost in the world. The continuous permafrost zone occupies a significant area in Russia (see Fig. 1). Russia also has the greatest expanse of wetlands (Tyuremnov 1976). The occurrence of wetlands within the permafrost zone is common. Disruption of the carbon cycle within the permafrost zone of Russia could have a profound effect on the global terrestrial carbon cycle. To assess the role of the Russian permafrost environment in the global carbon cycle it is necessary to establish a framework in which the carbon balance under the present climate can be quantified. Following an understanding of the 
carbon balance under the present climate it may be possible to assess changes in the carbon pools and fluxes under a warming climate.

The purpose of the paper presented here is to (1) estimate the carbon balance of the continuous permafrost zone in Russia under the present climate, and (2) assess the significance of the ecosystems in the continuous permafrost zone to the global carbon cycle.

\section{METHODOLOGY}

The terrestrial carbon cycle consists of a combination of carbon pools and fluxes. The pools are carbon stores in soil and vegetation, including living vegetation (i.e. phytomass) and plant detritus (i.e. mortmass and litter). The term mortmass is used to describe above-ground and below-ground coarse woody debris. The term litter is used to describe an upper soil layer which consists of undecomposed leaves and fine woody debris. The effluxes are carbon emissions resulting from plant respiration and decomposition of organic matter. The processes of formation of new organic matter in soil and vegetation [i.e, humus and foliage formation, and net primary productivity (NPP)] may be considered to represent carbon influxes

NPP equals the difference between gross photosynthesis (GPP) and respiration of autotrophic organisms $\left(R_{A}\right) . R_{\mathrm{A}}$ amounts to approximately 44 to $52 \%$ (48\% on average) (Kobak 1988) of GPP. Root respiration $\left(R_{\text {Ar }}\right)$ comprises one-third of $R_{\mathrm{A}}$. An ecosystem sequesters carbon during a specific phase of development (Odum 1953). The parameter that characterizes this carbon storage is called net ecosystem productivity (NEP). NEP equals the difference between NPP and carbon loss resulting from heterotrophic respiration $\left(R_{\mathrm{H}}\right)$. In the present study it was assumed that NPP equals $R_{H}$ and, therefore, the ecosystems within the permafrost zone are in a state of equilibrium.

Carbon fluxes can be measured or estimated. However, when carbon effluxes are measured the contribution from different processes cannot be distinguished. For example, when soil carbon efflux is measured, it is hard to distinguish between effluxes resulting from $R_{\mathrm{Ar}}$ and decomposition of litter, belowground mortmass, and soil organic matter $\left(R_{\mathrm{Hb}}\right)$. The quantitative method allows one to separate these fluxes.

Carbon effluxes were calculated from the influxes assuming that all ecosystems were in an equilibrium state. The carbon efflux from mortmass decomposition was assumed to be equal to mortmass production. In turn, mortmass production was assumed to be equal to phytomass production (NPP and production of different parts of plants). The carbon efflux from litter decomposition was calculated as the difference between foliage formation (green-assimilating parts production) and the sum of total humus formation and peat accumulation. The carbon efflux from soil organic matter decomposition was calculated as the difference between total and stable humus formation. The carbon efflux from $R_{A r}$ was calculated from NPP, assuming that $R_{\mathrm{Ar}}$ comprises one-third of the total $R_{\mathrm{A}} ; R_{\mathrm{A}}$ comprises $48 \%$ (on average) of the GPP; NPP equals the difference between GPP and $R_{\mathrm{A}}$. The sum of $R_{\mathrm{Ar}}$ and $R_{\mathrm{Hb}}$ (below-ground mortmass, litter, and soil organic matter decomposition) was compared with field measurements of the surface soil carbon efflux (Kobak 1988).

To assess a carbon balance of any region, the geographic area within which it can be quantified must be isolated. The term ecoregion was applied to the boundaries and areal extent of the geographic area with assumed uniform vegetation and soils. The term ecosystem was applied to the combination of certain soil-vegetation formations within an ecoregion. The term biome was applied to the complex of ecosytems within a climatic belt or sub-belt.

The carbon cycle parameters may be expressed in terms of carbon content (for pools) or rate per hectare (for influxes or effluxes) for a variety of soil-vegetation complexes. If the soil-vegetation complexes are related to the natural attributes identified on maps that are used to isolate ecoregions, then the carbon balance for an ecoregion can be established simply by multiplying the area of the ecoregion (in hectares) by the carbon content(s) and rate(s). The carbon contents and rates for all the ecoregions may be summed to arrive at the carbon balance for a larger region, biome or nation.

Isolation of ecoregions. The territory of the Russian Republic was categorized by the soil-vegetation type of the ecosystem, the presence of continuous permafrost, and the presence of wetlands. Maps containing information on the distribution of zonal soil-vegetation associations within Russia (Ryabchikov 1988), distribution of permafrost (Yershov et al. 1985), and wetlands (Isachenko 1988) were digitized and computer-superimposed with a geographical information system (GIS) (Burrough 1986). The map with the distribution of soilvegetation associations (Ryabchikov 1988) provided the basis for ecoregion isolation. After computer superimposition of the maps noted above, different ecosystems (i.e. soil-vegetation associations) within the permafrost zone in Russia were identified.

The ecosystems within the permafrost zone were aggregated into 4 biomes. The polar desert biome included areas covered by ice and stony barrens. The tundra biome included herbaceous and shrub tundra formations of polar and subpolar belts on dry cryic, arctic, peat, turf, gleyic, 'podbur', and podzolized soils. 
The forest-tundra biome included forest ecosystems with sparse forest cover on peat-turf, podzol and 'podbur' soils. The taiga biome included coniferous forests of the boreal climatic belt mainly on cryic-taiga and turf-podzolic soils. Peatlands (peatlands are wetlands where peat is accumulating) were identified within 3 biomes. The amount of carbon stored in soil and vegetation of the polar desert biome is insignificant. Consequently, this biome was excluded from the present study.

Vegetation parameters. Bazilevich (1986) compiled a data base which provides site-specific values for total phytomass content and phytomass productivity for 10 tundra and 40 forest-tundra and forest vegetation formations in Russia. These vegetation complexes were correlated to the ecosystems presented by Ryabchikov (1988). The data base allows the assessment of phytomass and the phytomass allocation increment. Phytomass is categorized as green-assimilating, woody above- (stems and branches), and below-ground (roots and buried stems) parts of plants. Mortmass is categorized as woody above-ground parts of plants (dead stems and branches), below-ground parts of plants, and litter. Productivity of phytomass, or NPP, was categorized in the same manner as phytomass. The net carbon content of plant mass was assumed to be $50 \%$ (Kobak 1988). This percentage was used to calculate the net carbon storage and rates of carbon accumulation in vegetation.

Only part of the taiga biome is within the permafrost zone. Permafrost has a marked effect on the features of growing trees (Muller 1947). Many tree species are absent in areas with permafrost. Larch, spruce, and dwarfed birch and pine are characteristic species for permafrost areas. It was important to identify the correct vegetation complexes in the Bazilevich data base and correlate them to the ecosystems identified. In the present study larch stands (west Siberia) and birch stands (European part) of the forest-tundra zone were used to characterize the forest ecosystems of the forest-tundra biome. Spruce stands (western and eastern European parts) of the northern taiga zone were used to characterize forest ecosystems of the taiga biome. Transitional peatlands (European part) of the taiga zone were used to characterize peatlands of the taiga biome. Continental meadows (Europe) were used to characterize the meadows of the taiga biome. Typical tundra formations (eastern European part) and peatlands of the tundra zone were used to characterize the ecosystems of the tundra and forest-tundra biomes.

Soil parameters. Kobak's (1988) data base was used to characterize soils in the permafrost zone. The data base includes carbon content of soils (total and stable organic matter for a $1.0 \mathrm{~m}$ layer of inorganic soil and the total thickness of organic peat soils), the annual rate of foliage and humus formation (total and stable), and the $\mathrm{CO}_{2}$ efflux from soils. Kobak (1988) reports the following names of soil types that may be related to the Russian polar desert and tundra biomes: arctic, tundragleyic and peat soil. Soils that may be related to the forest-tundra and taiga biomes are mainly cryic-taiga soils, meadow, and peat soils.

The depth of peat depends on the age, character of the vegetation, geographical location of peatlands, etc. In high latitudes the severe climate inhibits peat formation. As a rule, peatlands in the zone of continuous permafrost are shallow; the thickness of peat does not exceed half a meter (Botch pers. comm. 1992) with the exception of relict polygonal mires, where the thickness may be significantly greater (Botch \& Masing 1983). The exact extent of relict polygonal mires remains uncertain. Therefore, they were not considered in the present study.

The minimum carbon content of peat soils reported by Kobak (1988) is $470 \mathrm{tha}^{-1}$. This value was assigned to peatlands within the continuous permafrost zone. There are no published data on the annual rate of peat formation in peatlands of the continuous permafrost zone. The present assessment of annual peat accumulation (approximately $0.1 \mathrm{t} \mathrm{C} \mathrm{ha-1} \mathrm{yr}^{-1}$ ) was based on recent estimates performed by Botch \& Kobak (pers. comm. 1992).

Integration of ecoregion areas and carbon data. Carbon pools and fluxes for natural ecosystems of the Russian continuous permafrost zone were estimated by integrating the carbon data and the GIS analysis results (hectare data) using commercially available spreadsheet software (Microsoft Corporation 1991). Productivity of green-assimilating parts of plants was used to characterize the rate of foliage formation. Data on carbon content, the rate of carbon accumulation in peatlands, and methane emissions from wetlands (Matthews \& Fung 1987) were integrated with the hectare data of wetlands. Carbon effluxes were estimated from influxes as previously discussed.

\section{RESULTS AND DISCUSSION}

\section{Area estimates in the permafrost zone}

The area of the continuous permafrost zone in Russia was estimated at 824.2 Mha ( 1 Mha $=10^{6}$ hectares). The continuous permafrost zone was approximately $40 \%$ of the territory for Russia, and $5 \%$ of the land surface area of the world. The area of the 3 biomes with significant carbon content in the continuous permafrost zone was estimated at 772.1 Mha. The areas of tundra ecosystems and peatlands within the tundra biome were estimated at 211.3 and $2.9 \mathrm{Mha}$, respec- 
Table 1 Vegetation, litter, and soil carbon contents for ecosystems of the continuous permafrost zone of Russia

\begin{tabular}{|c|c|c|c|c|c|c|c|c|}
\hline \multirow[t]{2}{*}{ Biome } & \multirow[t]{2}{*}{ Ecosystem } & \multirow{2}{*}{$\begin{array}{l}\text { Area } \\
\text { (Mha) }\end{array}$} & \multicolumn{2}{|c|}{ Phytomass ( $\mathrm{C} \mathrm{ha}^{-1}$ ) } & \multicolumn{2}{|c|}{ Mortmass ( $\mathrm{C} \mathrm{ha} \mathrm{a}^{-1}$ ) } & \multirow{2}{*}{$\begin{array}{c}\text { Litter } \\
\text { (t Cha-1) }\end{array}$} & \multirow{2}{*}{$\begin{array}{l}\text { Soil (peat) } \\
\left.\text { (t } C \mathrm{ha}^{-1}\right)\end{array}$} \\
\hline & & & Below-ground & Total & Below-ground & Total & & \\
\hline \multirow[t]{2}{*}{ Tundra } & Tundra & 211.3 & 5.8 & 8.7 & 11.2 & 17.1 & 4.8 & 200 \\
\hline & Peatland & 2.9 & 7.2 & 11.7 & 22.7 & 48.2 & 24.9 & 470 \\
\hline \multirow{3}{*}{$\begin{array}{l}\text { Forest- } \\
\text { tundra }\end{array}$} & Forest & 187.0 & 10.4 & 20.8 & 15.6 & 35.2 & 17.8 & 150 \\
\hline & Tundra & 95.7 & 5.8 & 8.7 & 11.2 & 17.1 & 4.8 & 200 \\
\hline & Peatland & 5.0 & 7.2 & 11.7 & 22.7 & 48.2 & 24.9 & 470 \\
\hline \multirow[t]{3}{*}{ Taiga } & Forest & 175.6 & 14.1 & 55.8 & 7.0 & 20.0 & 7.0 & 150 \\
\hline & Meadow & 87.9 & 3.4 & 4.8 & 3.4 & 4.4 & 0.0 & 190 \\
\hline & Peatland & 6.7 & 8.2 & 24.8 & 2.2 & 5.1 & 31.7 & 470 \\
\hline
\end{tabular}

tively. The areas of forest and tundra ecosystems in the forest-tundra biome were estimated at 187.0 Mha and 95.7 Mha, respectively, assuming that forest ecosystems cover approximately $65 \%$ of the land in the northern forested regions of Russia (Vorobyov 1985). The area of peatlands was estimated at 5.0 Mha. The area of forest ecosystems in the taiga biome was estimated at 175.6 Mha. Meadow ecosystems occupied 87.9 Mha. The area of peatlands was estimated at 6.7 Mha. The wetland map that was used in the present study substantially underestimates the extent of peatlands (and possibly wetlands) in many areas, e.g. northern part of Siberia, Far East (Botch \& Kobak pers. comm. 1992). The peatland and wetland areas may be an order of magnitude greater. The current map was used to develop the methodology to assess the carbon cycle of the continuous permafrost zone in Russia. The methodology developed allows the replacement of one map with another, as well as the use of different data bases.

\section{Carbon pools}

Carbon contents of vegetation, litter, and soils of the ecosystems within the continuous permafrost zone of Russia are presented in Table 1. The total phytomass carbon pool for 3 biomes within the permafrost zone was estimated at $17.0 \mathrm{Gt}$ with $1.9,4.8$ and $10.3 \mathrm{Gt} \mathrm{C}$ in the tundra, forest-tundra and taiga biomes, respectively. The total mortmass carbon pool was estimated at $16.1 \mathrm{Gt}$, with $3.8,8.5$ and $3.9 \mathrm{Gt}$ in the tundra, foresttundra, and taiga biomes, respectively.

The percentage of below-ground phytomass and mortmass increased from south to north (from the taiga to the tundra biome). The major portion of carbon $(73 \%)$ in phytomass of the taiga biome was concentrated in above-ground parts. In the forest-tundra biome the share of above-ground phytomass was greater $(47 \%)$. The bulk of carbon $(67 \%)$ in the phyto- mass of the tundra biome was concentrated belowground. Below-ground mortmass was 49 and $39 \%$ in the forest-tundra and taiga biomes, respectively. In the tundra biome $65 \%$ of the mortmass carbon pool was concentrated below-ground.

The litter carbon pool was estimated at $6.4 \mathrm{Gt}$, with 1.1, 3.9 and $1.4 \mathrm{Gt}$ in the tundra, forest-tundra and taiga biomes, respectively. The total soil carbon pool was estimated at $132.5 \mathrm{Gt}$, distributed approximately equally between the biomes $(42.3,47.2$ and $43.0 \mathrm{Gt}$ in the tundra, forest-tundra, and taiga biome, respectively). The stable humus pool was $67 \%$ of the total humus carbon pool. The peatland carbon pool was 6.9 Gt $C(1.4,2.4$ and $3.1 \mathrm{Gt} C$ in the tundra, foresttundra and taiga biome, respectively). Tundra ecosystems in Russia accumulated approximately $87 \%$ of the carbon concentrated in the world tundra biome (61 Gt; Oechel 1989). Of the dead organic matter concentrated in the world's arctic ecosystems $(50 \mathrm{Gt} \mathrm{C}$; Oechel et al. 1993), $92 \%$ is contained below-ground in the Russian tundra biome.

The phytomass carbon pool in the continuous permafrost zone of Russia was $19 \%$ of the phytomass carbon pool for Russia and $3 \%$ of the world biomass carbon pool (Fig. 2) (Kobak 1988, Kolchugina \& Vinson 1991, Vinson \& Kolchugina 1993). The litter carbon was approximately one-third of the FSU litter pool, and one-tenth of the global detritus pool - the term 'detritus' was used by Kobak to define litter (Kobak \& Kondrashova 1987). Soil carbon was $35 \%$ of the FSU and $7 \%$ of the world pools.

\section{Carbon fluxes}

Table 2 presents the rate of organic matter formation (influxes) in the ecosystems of the continuous permafrost zone of Russia. NPP was estimated at approximately $1.6 \mathrm{Gt} C \mathrm{yr}^{-1}$. Production of woody above-ground and below-ground parts, and green- 

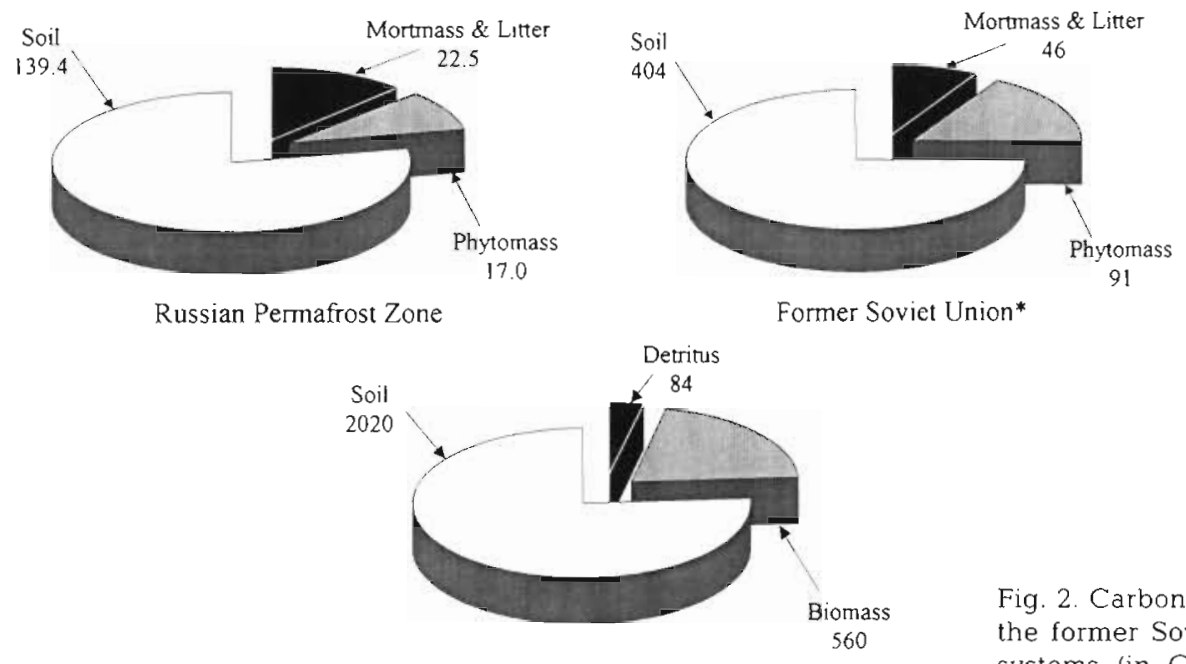

World**

Fig. 2. Carbon pools of the Russian permafrost zone the former Soviet Union, and world terrestrial ecosystems (in Gt C). "Kolchugina \& Vinson (1991); - Kobak (1988)

assimilating parts (i.e. foliage formation) was

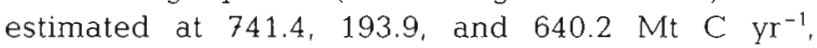
respectively. Total humus formation was estimated at 82.6 $\mathrm{Mt} \mathrm{C} \mathrm{yr}^{-1}$, with $34.5 \mathrm{Mt}$ accumulating in the stable form. Peat accumulation was estimated at $1.5 \mathrm{Mt} \mathrm{C}$ $\mathrm{yr}^{-1}$. Methane production from peatlands was esti-

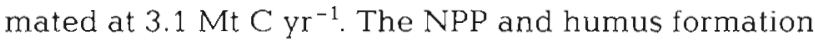
were 25 and $31 \%$, respectively, of the total FSU NPP and humus formation (Fig. 3). The NPP and humus formation for the continuous permafrost zone were 2 and $3 \%$, respectively, of the same parameters estimated for the world terrestrial ecosystems.

The equilibrium carbon balance of the continuous permafrost zone of Russia is presented in Fig. 4. Plant detritus (mortmass and litter) exceeded live vegetation (phytomass) by approximately $30 \%$. Live vegetation and plant detritus taken together were approximately $30 \%$ of the soil (with peat) carbon pool. Some of the soil organic matter may be formed from below-ground mortmass. At present, the exact amount of belowground mortmass transformed to soil organic matter remains uncertain (Kobak 1988).

The carbon efflux from mortmass decomposition was assumed to be equal to the production of woody parts (see 'Methodology'). The carbon efflux from below-ground mortmass decomposition was significant (640.1 $\mathrm{Mt} \mathrm{yr}^{-1}$ ) and approximately equal to the

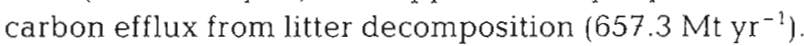
The carbon efflux from soil organic matter decom-

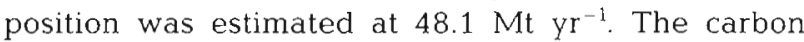
effluxes from below-ground mortmass and litter decomposition each exceeded the carbon efflux from

Table 2. Rate of organic matter formation for ecosystems of the continuous permafrost zone of Russia

\begin{tabular}{|c|c|c|c|c|c|c|c|c|c|}
\hline \multirow[t]{2}{*}{ Biome } & \multirow[t]{2}{*}{ Ecosystem } & \multicolumn{8}{|c|}{ Production (influx) (MtC $\left.\mathrm{yr}^{-1}\right)$} \\
\hline & & $\begin{array}{l}\text { Total } \\
\text { (NPP) }\end{array}$ & $\begin{array}{l}\text { Woody above- } \\
\text { ground parts }\end{array}$ & $\begin{array}{l}\text { Woody below- } \\
\text { ground parts }\end{array}$ & $\begin{array}{l}\text { Green assimilat- } \\
\text { ing parts (foliage) }\end{array}$ & $\begin{array}{l}\text { Total } \\
\text { humus }\end{array}$ & $\begin{array}{l}\text { Stable } \\
\text { humus }\end{array}$ & Peat & $\begin{array}{l}\mathrm{CH}_{4} \\
\text { release }\end{array}$ \\
\hline \multirow[t]{3}{*}{ Tundra } & Tundra & 227.1 & 15.8 & 84.5 & 126.8 & 10.6 & 4.2 & & \\
\hline & Peatland & 6.7 & 0.1 & 3.3 & 3.3 & 0.2 & 0.1 & 0.3 & 0.4 \\
\hline & Total & 233.8 & 15.9 & 87.8 & 130.1 & 10.8 & 4.3 & 0.3 & 0.4 \\
\hline \multirow{4}{*}{$\begin{array}{l}\text { Forest- } \\
\text { tundra }\end{array}$} & Forest & 342.3 & 31.8 & 127.2 & 183.3 & 20.6 & 9.4 & & \\
\hline & Tundra & 102.9 & 7.2 & 38.3 & 57.4 & 4.8 & 1.9 & & \\
\hline & Peatland & 11.7 & 0.2 & 5.6 & 5.8 & 0.3 & 0.2 & 0.5 & 1.0 \\
\hline & Total & 456.9 & 39.2 & 171.1 & 246.5 & 25.7 & 11.5 & 0.5 & 1.0 \\
\hline \multirow[t]{4}{*}{ Taiga } & Forest & 405.7 & 137.0 & 93.1 & 175.6 & 19.3 & 8.8 & & \\
\hline & Meadow & 470.3 & 0.0 & 285.7 & 184.6 & 26.4 & 9.7 & & \\
\hline & Peatland & 8.9 & 1.8 & 2.5 & 4.6 & 0.4 & 0.2 & 0.7 & 1.7 \\
\hline & Total & 884.9 & 138.8 & 381.3 & 364.8 & 46.1 & 18.7 & 0.7 & 1.7 \\
\hline \multicolumn{2}{|c|}{ All ecosystems } & 1575.5 & 193.9 & 640.2 & 741.4 & 82.6 & 34.5 & 1.5 & 3.1 \\
\hline
\end{tabular}



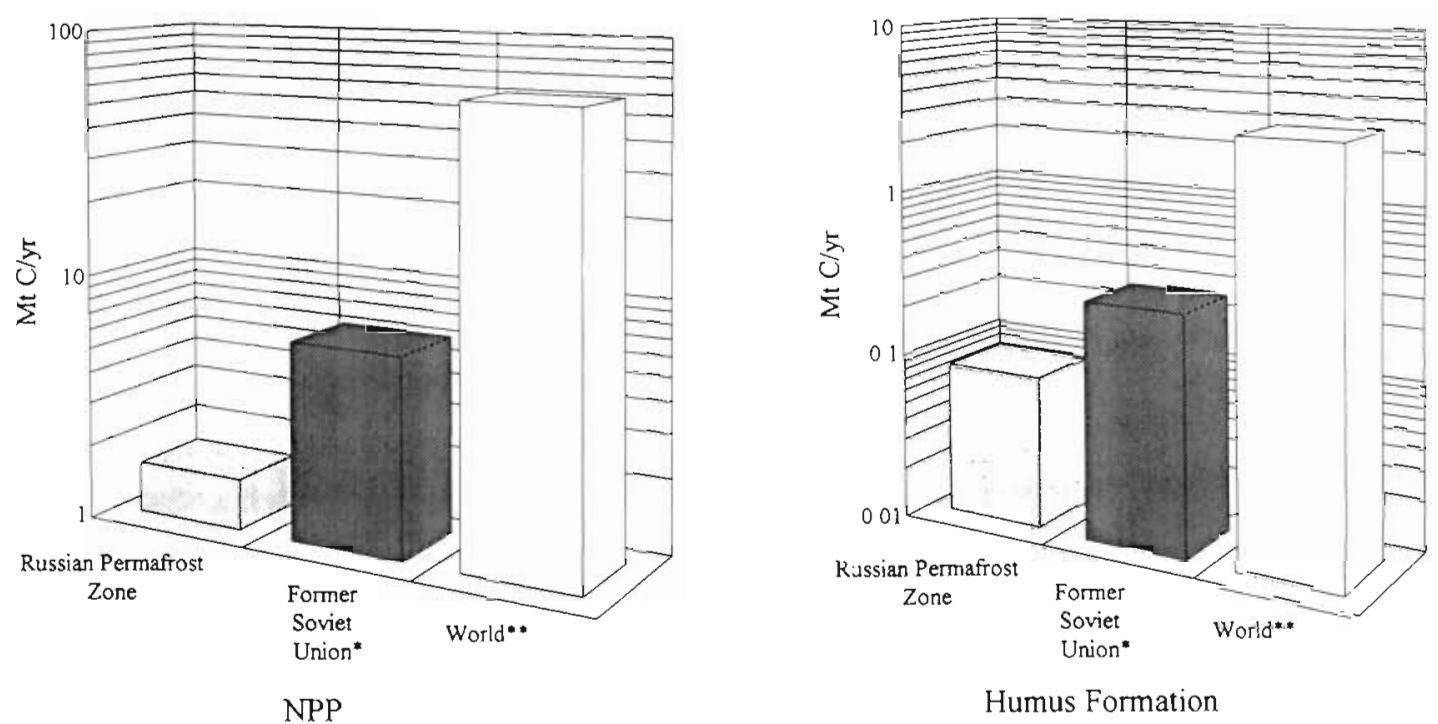

Fig. 3. NPP and humus formation in the Russian permafrost zone, the former Soviet Union, and world terrestrial ecosystems. 'Kolchugina \& Vinson (1991); " Kobak (1988)

soil organic matter decomposition by more than an order of magnitude.

$R_{\mathrm{A}}$ was estimated with the methodology previously described at approximately $1.46 \mathrm{Gt} \mathrm{C} \mathrm{yr}^{-1}$. $R_{\mathrm{Ar}}$ was estimated at $0.49 \mathrm{Gt} \mathrm{C} \mathrm{yr}^{-1}$. Carbon efflux from the soil surface (including $R_{\mathrm{Hb}}$ and $R_{\mathrm{Ar}}$ ) was $2.27 \mathrm{Gt} \mathrm{C} \mathrm{yr^{-1 }}$ or approximately $40 \%$ greater than the efflux estimated from Kobak's (1988) data (i.e. $1.59 \mathrm{Gt} \mathrm{C} \mathrm{yr}^{-1}$ for the same area). Kobak's data for emissions from the soil surface are based on site-specific field measurements. The carbon efflux from the soil surface could have been underestimated by the field measurements methods (e.g. absorption method) that were used. Further, Kobak reports a length of vegetation growing season in different biomes. However, soil carbon efflux may not be limited by the length of the growing season (Zimov et al. 1991). In the present study the carbon efflux from the soil surface was estimated from NPP. If NPP was overestimated the soil surface carbon efflux would also be overestimated

The methane emissions from wetlands were approximately $1.2 \times 10^{35}$ molecules of $\mathrm{CH}_{4} \mathrm{yr}^{-1}$. The total carbon emissions from the decomposition processes were approximately $204.2 \times 10^{35}$ molecules $\mathrm{CO}_{2} \mathrm{yr}^{-1}$. The
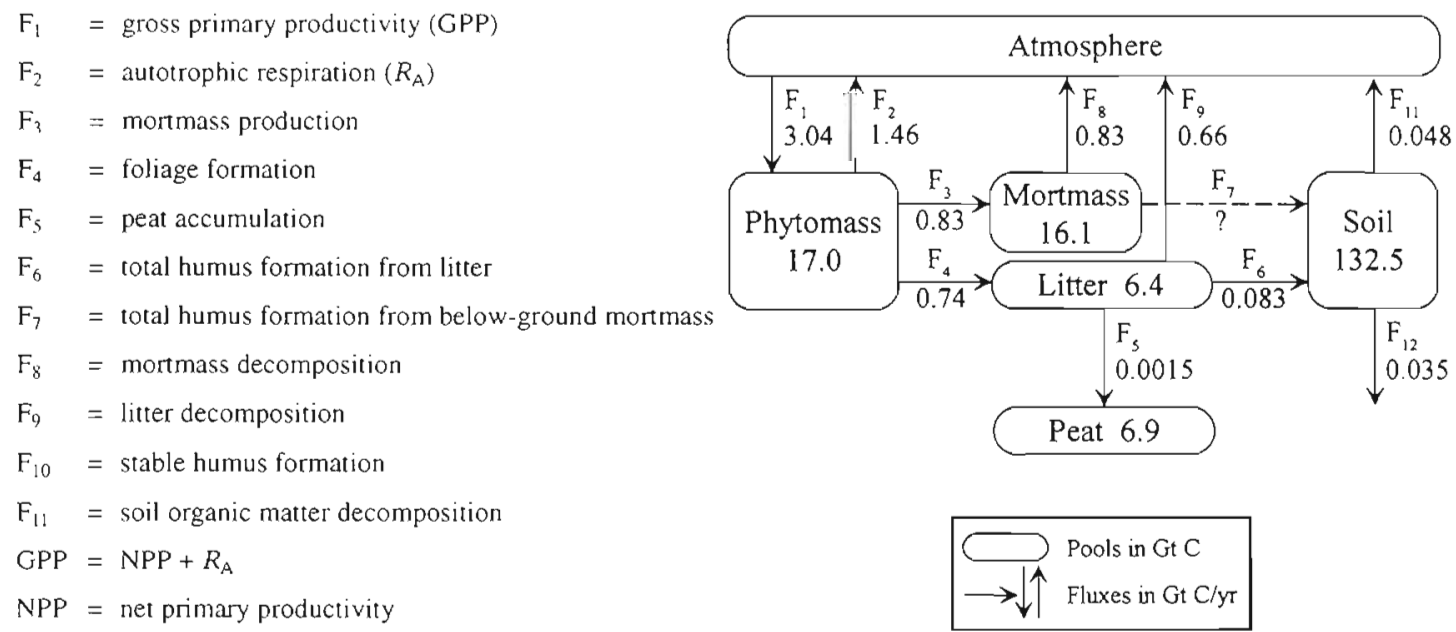

Fig. 4. Equilibrium carbon balance for the permafrost zone of Russia 
$\mathrm{CH}_{4}$ molecule is 20 times more effective than $\mathrm{CO}_{2}$ as a greenhouse gas (Blake \& Rowland 1988). Therefore, $1.2 \times 10^{35}$ molecules $\mathrm{CH}_{4}$ would be equivalent to $24 \times 10^{35}$ molecules $\mathrm{CO}_{2}$, or to $12 \%$ of the total emissions from the decomposition processes. If the wetland area was underestimated by an order of magnitude, methane emissions from wetlands would be equivalent to the total carbon dioxide emissions from decomposition processes with respect to potency as a greenhouse gas.

The below-ground carbon pool of arctic ecosystems (50 Gt C) may be consumed within 3 centuries assuming the present rate of carbon loss reported by Oechel

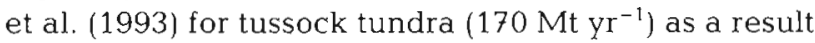
of a decrease in the water table, and enhanced drainage and soil aeration which might occur with warming. Nutrient availability is one of the most important factors that limits plant growth and, therefore, carbon gain in the arctic. Soil drainage may be accompanied by the loss of nutrients from the ecosystems and result in decreased productivity. The nutrient limitation is especially important in herbaceous tundra vegetation where the $\mathrm{C} / \mathrm{N}$ ratio is significantly lower (20:1 to 50:1) compared to woody plants (200:1) (Shaver et al. 1992). Thus, stable or increased productivity may be expected in ecosystems with woody vegetation (e.g. shrubs and trees). According to available FSU soil-vegetation maps shrubby tundra formations occupied approximately one-half of the area of the tundra biome.

Thawing of permafrost may compensate for the water deficiency in the tundra biome. Retention of water and nutrients released from enhanced decomposition of organic matter may be expected within the area of soils with low permeability, e.g. gleyic soils. In this case nutrients may be physically or chemically sorbed on soil particles with high sorption. Gleyic soils were identified within approximately half of the tundra area. In addition, the permafrost table may be a barrier preventing nutrient loss. These conditions may promote an increase in plant productivity. Further, the migration of the tree line to the north with climate warming (Viereck \& Van Cleve 1984, Maxwell 1987) may also increase carbon uptake from the atmosphere and compensate for carbon losses from decompositional processes in the region.

The thickness of the active layer in areas with peat and swamps is 0.2 to $0.4 \mathrm{~m}$ along the coast of the Arctic Ocean, increasing to $1.0 \mathrm{~m}$ south of the 55 th parallel (Muller 1947). The depth of the active layer in mineral soils is substantially greater; it exceeds the depth of the organic horizons. Warming may double or even triple the active layer (Smith \& Riseborough 1983, Kane et al. 1991). In peatlands this process could make an additional mass of organic matter available for decomposi- tion. However, thawing of the active layer in peatlands may not be this great, because of the low thermal conductivity and high latent heat capacity of peat. Thus, the degradation of permafrost would not directly affect the rate of carbon emissions from the mineral soils and peatlands. With permafrost degradation deep layers of buried organic horizons of the mineral soils may become available for decomposition. At present their areal extent and carbon stores remain unknown. Thus, their role in the carbon cycle under a warming climate is uncertain.

Acknowledgements. The work presented here is a component of the U.S. EPA Global Mitigation and Adaptation Program, Robert K. Dixon, Program Leader. Jeffrey J. Lee is the Project Officer for the project entitled 'Carbon Cycling in Terrestrial Ecosystems of the Former Soviet Union'. The research described in this paper was funded by the U.S. Environmental Research Laboratory in Corvallis, Oregon, through Cooperative Agreement CR 820239-01-0 with Oregon State University. The paper is currently under the Agency's peer and administrative review. Mention of trade names or commercial products does not constitute endorsement or recommendation for use.

\section{LITERATURE CITED}

Bartlett, K. B., Bartlett, D. S., Sebacher, D. I. (1985). Methane flux from coastal salt marshes. J. geophys. Res. 90: $5710-5720$

Bazilevich, N. I. (1986). Biological productivity of soilvegetation formations in the USSR. Bull. Acad. Sci. USSR. Geograph. Ser. 2: 49-66 (in Russian)

Billings, W. D., Luken, J. O., Mortensen, D. A., Peterson, K. M. (1982). Arctic tundra: a source or sink for atmospheric carbon dioxide in a changing environment? Oecologia 53: 7-11

Blake, D. R., Rowland, F. S. (1988). Continuing worldwide increase in stratospheric methane, 1978-1987. Science 239: $1129-1131$

Botch, M. S., Masing, V V. (1983). Mire ecosystems of the USSR. In: Gore, A. J. P. (ed.) Ecosystems of the world, mires: swamp, bog, fen, and moor. Regional studies, Vol. 4B. Elsevier, New York, p. 95-152

Burrough, P. A. (1986). Principles of geographical information systems for land resources assessment. Clarendon Press. Oxford

Chapin, F. S. III (1984). The impact of increased air temperature on tundra plant communities. In: Proceedings of the Conference: The Potential Effects of Carbon DioxideInduced Climatic Changes in Alaska. School of Agriculture and Land Resources Management, University of Alaska, Fairbanks, p. 143-162

Chapin, F. S. III, Miller, P. C., Billings, W. D., Coyne, P. I. (1980). Carbon and nutrient budgets and their control in coastal tundra. In: Brown, J., Miller, P. C., Tieszen, L., Bunnell, F. L. (eds.) An arctic ecosystem: the coastal tundra at barrow, Alaska. Dowden, Hutchinson, and Ross, Stroudsburg, PA, p. 458-484

Chapin, F. S. III, Shaver, G. R. (1981). Changes in soil properties and vegetation during disturbance of Alaskan arctic tundra. J. appl. Ecol. 18: 605-617 
Davidson, D. W., El-Defrawy, M. K., Fuglem, M. O., Judge, A. S. (1978). Natural gas hydrates in northern Canada. In: Proceedings of the Third International Conference on Permafrost, Vol. 1. National Research Council of Canada, Ontario, p. $938-943$

Dixon, R. K., Turner, D. P. (1991). The global carbon cycle and climate change: responses and feedbacks from belowground systems. Environ. Pollut. 73: 245-262

Etkin, D. (1990). Greenhouse warming: consequences for arctic climate. J. Cold Reg. Engin. 4(1): 54-66

French, D. D. (1977). Multivariate characteristics of IBP Tundra Biome site characteristics. In: Bliss, L. S., Heal O. W., Moore, J. J. (eds.) Tundra ecosystems: a comparative analysis, Cambridge University Press, New York, p. $47-75$

Harriss, R. C., Gorham, E., Sebacher, D. I., Bartlett, K. B., Flebbe, P. A. (1985). Methane flux from northern peatlands. Nature 315: 652-653

Heal, O. W., Flagan, P. W., French, D. D., MacLean, S. F. Jr (1981). Decomposition and accumulation of organic matter in tundra. In: Bliss, L. S., Heal, O. W., Moore, J. J. (eds.) Tundra ecosystems: a comparative analysis. Cambridge University Press, New York, p. 587-633

IPCC (Intergovernmental Panel on Climate Change) (1990). Climate change, the IPCC scientific assessment. Cambridge University Press, Cambridge

Isachenko, A. G. (ed.) (1988). Landscape map of the USSR. Institute of Geography, Leningrad State University

Kane, D. L., Hinzman, L. D., Zarling, J. P. (1991). Thermal response of the active layer to climatic warming in a permafrost environment. Cold Reg. Sci. Tech. 19: 111-122

Kobak, K. I. (1988). Biotic components of the carbon cycle. Hydrometeoizdat, Leningrad (in Russian)

Kobak, K. I., Kondrashova, N. Yu. (1987). Anthropogenic impact on soil carbon reservoir and carbon cycle. Meteorol. Hydrol. 5: 39-46 (in Russian)

Kolchugina, T. P., Vinson, T. S. (1991). Framework to quantify the natural terrestrial carbon cycle of the former Soviet Union. In: Vinson, T., Kolchugina, T (eds.) Proceedings of the Workshop on Carbon Cycling in Boreal Forests and Subarctic Ecosystems, Corvallis, Oregon, Sept. 9-14. U.S. EPA, Corvallis, p. 257-273

Kvenvolden, K. A. (1988a). Methane hydrates and global climate. Global biogeochem. Cycles 2(3): 221-229

Kvenvolden, K. A. (1988b). Methane hydrate - a major reservoir of carbon in the shallow geosphere? Chem. Geol. 71: $41-51$

Kvenvolden, K. A., Grantz, A. (1990). Gas hydrates of the arctic ocean region. Arctic Ocean region. In: Grantz, A., Johnson, L., Sweeney, J. F. (eds.) The geology of North America, Vol. 50. Geol. Soc. of America, Boulder, $\mathrm{CO}$, p. $539-549$

Matthews, E., Fung, 1. (1987). Methane emission from natural wetlands: global distribution, area, and environmental characteristics of sources. Global biogeochem. Cycles 1(1): $61-86$

Maxwell, B. (1987). Atmospheric and climatic change in the Canadian arctic. Causes, effects, and impacts. A question of degrees. Canadian Arctic Research Committee 15(5): $2-6$
Microsoft Corporation (1991). Microsoft Excel. Redmond, WA Muller, S. W. (1947). Permafrost or permanently frozen ground and related engineering problems. J. W. Edwards, Inc., Ann Arbor, MI

Nadelhoffer, K. J., Giblin, A. E., Shaver, G. R., Linkins, A. E. (1992). Microbial processes and plant nutrient avalabilıty in arctic soils. In: Chapin, F. S. III, Jefferies, R., Reynolds, J., Shaver, G., Svoboda, J. (eds.) Physiological ecology of arctic plants: implications for climate change. Academic Press, New York, p. 281-300

Odum, E. P. (1953). Ecology. W. B. Saunders, Philadelphia

Oechel, W. C. (1989). Nutrient and water flux in a small arctic watershed: an overview. Holarct. Ecol. 12: 229-237

Oechel, W. C., Billings, W. D. (1992). Anticipated effects of global change on the carbon balance of arctic plants and ecosystems. In: Chapin, F. S. III, Jefferies, R., Reynolds, J., Shaver, G., Svoboda, J. (eds.) Physiological ecology of arctic plants: implications for climate change. Academic Press, New York, p. 139-168

Oechel, W. C., Hastings, S. J., Vourlitis, G., Jenkins, M., Riechers, G., Grulke, N. (1993). Recent change of Arctic tundra ecosystems from a net carbon dioxide sink to a source. Nature 361(11): 520-523

Ryabchikov, A. M. (ed.) (1988). Map: Geographical belts and zonal types of landscapes of the world. School of Geography, Moscow State University

Schneider, S. H. (1990). Global warming. Vintage Books, New York

Shaver, G. R., Billings, W. D., Chapin, F. S. III, Giblin, A. E., Nadelhoffer, K. J., Oechel, W. C., Rastetter, E. B. (1992). Global climate change and the carbon balance of arctic ecosystems. BioSci. 42(6): 433-441

Smith, M. W., Riseborough, D. W. (1983). Permafrost sensitivity to clumatic change. Proceedings of the Fourth lnternational Conference on Permafrost, Fairbanks, Alaska. July, 1983. National Academy Press, p. 1178-1183

Tyuremnov, S. N. (1976). Torfyanye mestorozhdeniya. Nedra (in Russian)

Viereck, L. A., Van Cleve, K. (1984). Some aspects of vegetataion and temperature relationships in the Alaskan taiga. In: Proceedings of the Conference: The Potential Effects of Carbon Dioxide-Induced Climatic Changes in Alaska. School of Agriculture and Land Resources Management, University of Alaska, Fairbanks, p. $129-142$

Vinson, T. S., Kolchugina, T P. (1993). Pools and fluxes of biogenic carbon in the former Soviet Union. Wat. Air Soil Pollut. (in press)

Vorobyov, G. I. (ed.) (1985). Forest encyclopedia. Sovetskaya Enciklopedia. Moscow (in Russian)

Yershov, E. D., Kondratyeva, K. A, Zamolotchikova, S. A., Trush, N. I., Dunaeva, Ye. N. (1985). The geocryological map of the USSR of 1:2500000 scale. School of Geology, Moscow State University

Zimov, S. A., Daviodov, S. P., Voropaev, Yu. V, Prosiannikov, S. F. (1991). Planetary maximum $\mathrm{CO}_{2}$ and ecosystems of the North. In: Vinson, T., Kolchugina, $T$ (eds.) Proceedings of the Workshop on Carbon Cycling in Boreal Forests and Subarctic Ecosystems, Corvallis, Oregon, Sept. 9-14. U.S. EPA, Corvallis, p. 21-34 